\title{
Polypeptide Components of Rice Dwarf Virus
}

\author{
Masanobu NaKata,* Kenzo FukunagA* and Naoji Suzuki* \\ 中田昌伸*・福永憲三*・鈴木直治*：イネ萎縮病ウイルスの構成ポリペプチド
}

\begin{abstract}
Polyacrylamide gel electrophoresis of the solubilized protein of rice dwarf virus (RDV), purified from RDV-infected rice plants, showed the virus to be composed of seven structural polypeptides. The molecular weights of these were calculated to be 193,$000 ; 152,000 ; 131,000 ; 110,000 ; 62,000 ; 46,000$ and 45,000 daltons. These were designated I, II, III, IV, V, VI, and VII respectively. Chymotrypsin-treatment of the virus was not effective for removing the outer components of capsid, whereas centrifugation of the virus through preformed cesium chloride gradients separated the preparation into four zones, top $(\mathrm{T})$, upper-middle $\left(\mathrm{M}_{1}\right)$, lower-middle $\left(\mathrm{M}_{2}\right)$, and bottom (B), the buoyant densities of these being $1.26,1.39-1.42,1.43$, and $1.46 \mathrm{~g} / \mathrm{ml}$ respectively. Recentrifugation of $\mathrm{M}_{1}$ through the cesium chloride gradients yielded three zones, $M_{1}, M_{2}$, and $B$, indicating that the latter two resulted from $M_{1}$ by the shearing effect of cesium chloride centrifugation. Electron microscopy and SDSpolyacrylamide gel electrophoresis of B showed complete loss of II and IV, and a marked decrease of VI and VII, indicating that VI and VII compose the outer capsomeres and II and IV are the amorphous polypeptides that surround the outer capsomeres. The inner core was found to contain I, III, and V, among these V seemed to be the internal protein associated with nucleic acid because this was readily released from virions by freeze-thawing together with nucleic acid.
\end{abstract}

(Received April 13,1978)

\section{Introduction}

RDV virions contain double-stranded (ds) RNA and RNA transcriptase that transcribes dsRNA into single-stranded (ss) RNA. In a series of studies on the screening of chemotherapeutants for this virus ${ }^{5,11,12)}$, we have attempted to screen some compounds that selectively inhibit RDV-RNA transcription in vitro, but do not inhibit E. coli DNA transcription in vitro. Skyrin, a red pigment produced by Endothia parasitica, was found to fulfil the requirement. Conversely, luteoskyrin, a pigment produced by Penicillium islandicum and is structurally related to skyrin, inhibits E. coli DNA transcription without inhibiting RDV-RNA transcription. Rugulosin, a yellow pigment produced by Endothia parasitica and is also structurally related to skyrin, inhibits $E$. coli DNA trascription strongly and RDV-RNA transcription weakly. The inhibitory effects of the latter two are closely correlated with their ability to bind to and form floccules with E. coli DNA or RDV-RNA in the presence of $\mathrm{Mg}^{2+}$. Skyrin does not form floccules with the nucleic acids in the

* Faculty of Agriculture, Kobe University, Rokkodai, Nadaku, Kobe, Japan 神戸大学農学部

The following abbreviation are used: $R D V$, rice dwarf virus; EDTA, ethylene-diaminetetraacetic acid; SDS, sodium dodecyl sulfate; TEMED, N, N, N', $\mathrm{N}^{\prime}$-tetramethyleneethylenediamine; TCA, trichloroacetic acid; SSC, $0.15 \mathrm{M}$ sodium chloride, $0.015 \mathrm{M}$ sodium citrate, $\mathrm{pH} 7.4 ; \mathrm{bis}, \mathrm{N}$, $\mathrm{N}^{\prime}$-methylene bisacrylamide; PTA, phosphotungustic acid; PEG, polyethylene glycol $(6,000)$. 
presence of $\mathrm{Mg}^{2+} .{ }^{12)}$ The result suggests that skyrin inhibits RDV-RNA transcription not by binding to the RNA but by binding to other components of the virus, possibly the polypeptides. This prompted us to examine polypeptide components of the virus, their location in the virion, and their relation to the RNA transcriptase activity.

This paper reports the results of experiments on the electrophoretic analyses of polypeptide components of the solubilized protein of the virus, and effects of different treatments of virions on the integrity and RNA transcriptase activity of the virus.

\section{Materials and Methods}

Virus purification. RDV was purified from leaves of rice plants, Norin-8, inoculated with viruliferous leafhoppers, Nephotettix cincticeps Uhl., which had been reared on RDV-infected rice plants. The method of purification was as described previously ${ }^{12)}$. The procedure involving homogenization of leaf tissues with the addition of $\mathrm{CCl}_{4}$ in phosphate buffer, $\mathrm{pH} 6.8$, precipitation of virus by low speed centrifugation with the addition of $\mathrm{PEG}$ and $\mathrm{NaCl}$, treatment with fluorocarbon (Daiflon S3), and two quasi-equilibrium sucrose gradient centrifugations, was found to be the most successful. Although the fluorocarbon treatment was presumed to remove some of the outerlayer components of the virus as pointed out by Reddy et al. ${ }^{7)}$, this was necessary because RDV virions are otherwise enveloped in a lipid-like material ${ }^{3)}$.

Assay of RDV-RNA transcriptase activity. The method was as described previously. The standard reaction mixture contained in a final volume of $0.25 \mathrm{ml}$ : $0.2 \mu$ moles each of ATP, GTP, and UTP, $2.0 \mu \mathrm{Ci}$ of ${ }^{3} \mathrm{H}$-UTP, $2.0 \mu$ moles of $\mathrm{MgCl}_{2}$, $1.0 \mu$ mole of phosphoenol pyruvate, $25 \mu \mathrm{g}$ of pyruvate kinase, $50 \mu \mathrm{g}$ of chymotrypsin, $25 \mu$ moles of Tris- $\mathrm{HCl}, \mathrm{pH} 8.5$, and $200 \mu \mathrm{g}$ of RDV. In the case of testing effects of chymotrypsin-pretreatment of virions on the enzyme activity, chymotrypsin was omitted from the reaction mixture. After $60 \mathrm{~min}$. at $35 \mathrm{C}$, the reaction was stopped by $5 \% \mathrm{TCA}$ and the radioactivity of resulting TCA-insoluble fraction was measured as described previously ${ }^{4)}$.

CsCl gradient centrifugation. Purified RDV drawn from sucrose gradients was suspended in $0.1 \mathrm{M}$ phosphate buffer, $\mathrm{pH} 6.8$, and centrifuged for $60 \mathrm{~min}$. at $24,000 \mathrm{rpm}$ in a Hitachi RP-40 rotor. The resulting pellet was resuspended in 1 $\mathrm{ml}$ of phosphate buffer, $\mathrm{pH} 6.8$, layered on a preformed $\mathrm{CsCl}$ gradient $(1.3$ to $1.5 \mathrm{~g} / \mathrm{ml}$ density range), and centrifuged for 2 hours at 39,000 rpm in a Hitachi RPS-50 rotor. Fractions were collected from the bottom of the tube and the density of each fraction was determined by measuring its refractive index using the formula: $\rho_{\mathrm{Cs} C 1}=$ $10.860 \mathrm{nD} 25 \mathrm{c}-13.4974$

To remove $\mathrm{CsCl}$, each fraction was taken in a glass tube, both ends of which were sealed with cellophane membranes, subjected to electrophoresis for $6 \mathrm{hr}$ at $2 \mathrm{~mA} / \mathrm{tube}$, and then concentrated in a Ultra-Thimble (Schleicher \& Schuell). The sample was used for assaying RNA transcriptase activity.

Chymotrypsin treatment of purified RDV. One $\mathrm{mg}$ of purified RDV was suspended in $1 \mathrm{ml}$ of $\mathrm{lxSSC}$, pH 7.4, containing $200 \mu \mathrm{g}$ of chymotrypsin and incubated at $25 \mathrm{C}$ or $35 \mathrm{C}$ for $1 \mathrm{hr}$. The suspension was centrifuged at $24,000 \mathrm{rpm}$ in a Hitachi RP-40 rotor for $1 \mathrm{hr}$. The resulting pellent was resuspended in appropriate buffers and used for the assay of RNA transcriptase activity and the electrophoretic analysis of polypeptides.

SDS-polyacrylamide gel electrophoresis. Condition for electrophoresis of SDS gels were essentially as described by Smith et $a l .{ }^{10)}$ and Reddy et $a l .{ }^{7}$ ). Ten percent acrylamide gels, containing $0.267 \%$ bis, $0.1 \%$ SDS, 0.002 M EDTA, 0.1\% TEMED, 
and $0.15 \%$ ammonium persulfate were prepared in $0.1 \mathrm{M}$ sodium phosphate buffer, $\mathrm{pH}$ 7.4. The electrophoresis tank buffer was $0.1 \mathrm{M}$ sodium phosphate buffer, pH7.4, containing $0.1 \%$ SDS, $0.002 \mathrm{M}$ EDTA. Electrophoresis was performed at room temperature using 6-9 gel columns, $6 \mathrm{~mm} \times 100 \mathrm{~mm}$, at $5 \mathrm{~mA} / \mathrm{gel}(25-30 \mathrm{~V})$, for 16 to 21 hr. Besides, $8 \mathrm{~mm} \times 150 \mathrm{~mm}$ gel columns were used for determining the molecular weights polypeptides.

To solubilize the virus protein, samples were suspended in $0.01 \mathrm{M}$ phosphate buffer, pH 7.8, containing 1-2\% SDS, 0.002M EDTA, 1-2\% mercaptoethanol $(\mathrm{v} / \mathrm{v})$, and $10 \%$ sucrose, and treated in boiling water for $2 \mathrm{~min}$. Fifty to $200 \mu \mathrm{g}$ of the solubilized virus in less than $50 \mu 1$ was layered on each gel.

Following the electrophoresis, the gels were stained for $2-4 \mathrm{hr}$ in $0.2 \%$ coomasie brilliant blue in a glacial acetic acid: methanol: water (1:5:5) and destained overnight in $20 \%$ methanol in $7 \%$ acetic acid. The stained gels were scanned at $560 \mathrm{~nm}$ in a Yamato-Asuka Ozumor 8-2 Densitometer.

Molecular weight determination. Molecular weights of the RDV polypeptides were determined by the method of Shapiro et al. ${ }^{8)}$. Chymotrypsinogen A from beef pancreas (25,000; Dickinson \& Co.), ovalbumin (45,000; do.), bovine serum albumin $(67,000$; do.), and gamma globulin (160,000; do.) were used as markers.

Electron microscopy. Aliquots from the various preparations were dialyzed against $0.1 \mathrm{M}$ ammonium acetate, $\mathrm{pH} 6.0$, negatively stained with $2 \%$ phosphotungustic acid, pH7.0, and examined in a JEM 100 electronmicroscope.

\section{Results}

\section{SDS-polyacrylamide gel electrophoresis of RDV-polypeptides and determination of their molecular weights}

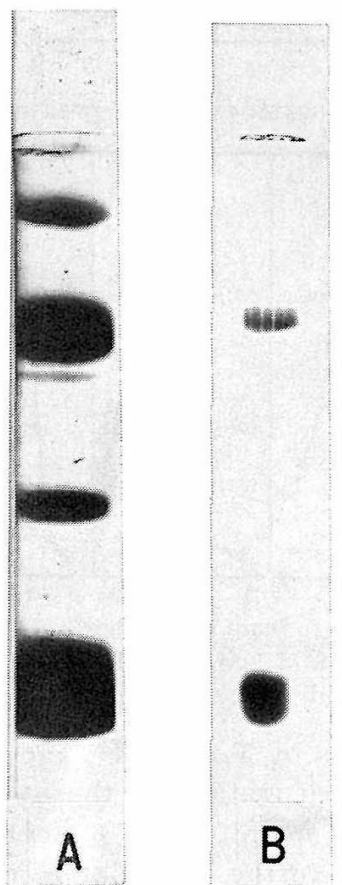

Fig. 1. Structural polypeptides of RDV virions as obtained on polyacrylamide gel electrophoresed: (A) Standard gel $(10 \%)$ (B) The separation of VI and VII components $(7.5 \% \mathrm{gel})$.

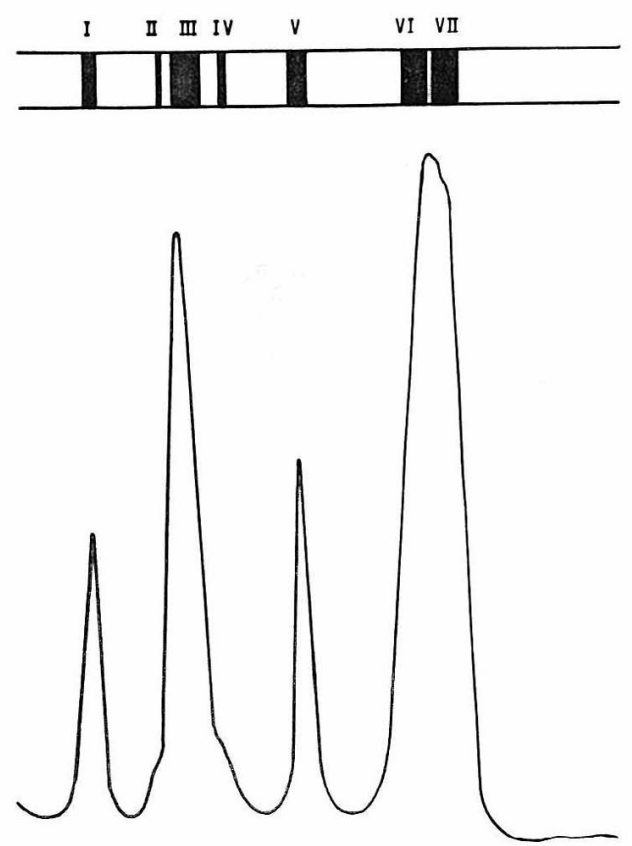

Fig. 2. Polyacrylamide gel electrophoresis profiles of polypeptide components of RDV virions. 


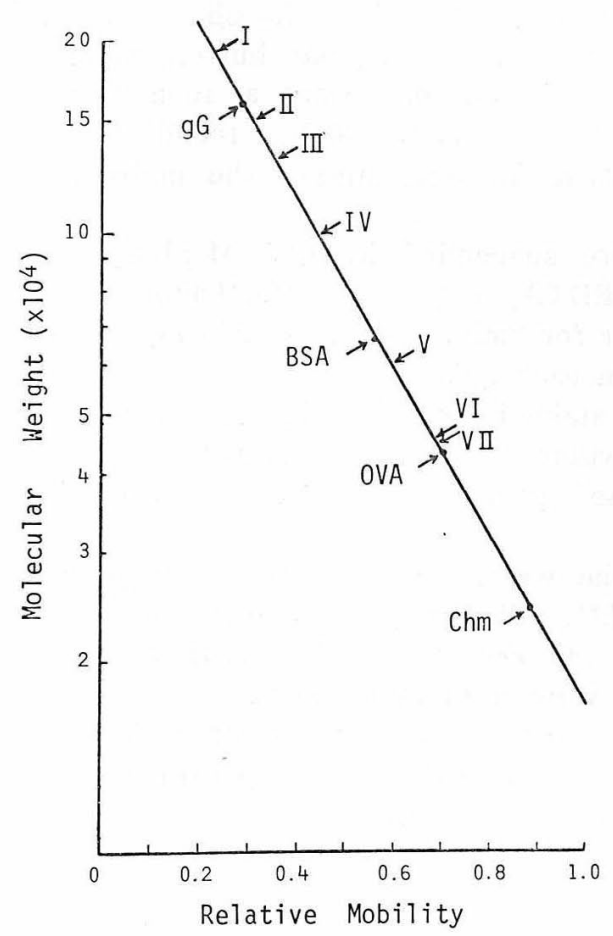

Fig. 3. Molecular weight determination of RDV polypeptides based on electrophoretic migration of assorted marker species. Abbreviation: gG, gamma globulin; BSA, bovine serum albumin; OVA, ovalbumin; Chy, chymotrypsinogen A.

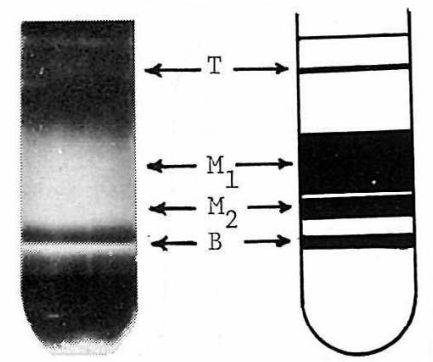

Fig.4. Isopycnic density gradient sedimentation patterns of RDV in preformed gradient of $\mathrm{CsCl}(\rho=1.3$ to $1.5 \mathrm{~g} / \mathrm{ml})$ for $2 \mathrm{hrs}$ at $39,000 \mathrm{rpm}$ in a Hitachi RPS -50 rotor: $\mathrm{T}$, top zone; $\mathrm{M}_{1}$, upper middle zone; $\mathrm{M}_{2}$, lower middle zone; $\mathrm{B}$, bottom zone.
Purified RDV samples drawn from sucrose gradients were solubilized by SDS and subjected to $10 \%$ polyacrylamide gel electrophoresis. The profiles show 6 bands, however the most mobile 6th band was separated into two bands when electrophoresis was performed on a $7.5 \%$ gel (Fig. 1,2). These were designated I, II, III, IV,V, VI, and VII in the order of molecular weights. Their molecular weights were calculated to be 193, 000; 152, 000; 131, 000; 110, 000; 62, 000; 46, 000 and 45,000 daltons respectively (Fig. 3 ).

\section{Degradation of $\mathrm{RDV}$ in $\mathrm{CsCl}$ density gradients}

Purified RDV sample drawn from sucrose density gradients were subject to equilibrium $\mathrm{CsCl}$ density gradient centrifugation. The samples were separated into four zones, $\operatorname{top}(T)$, upper-middle $\left(\mathrm{M}_{1}\right)$, lower-middle $\left(\mathrm{M}_{2}\right)$, and bottom (B). $\mathrm{M}_{1}$ was a broad zone, almost continuous to $\mathrm{M}_{2}$, but these were distinguishable because $\mathrm{M}_{1}$ was bluish- and $\mathrm{M}_{2}$ yellowish-opale-

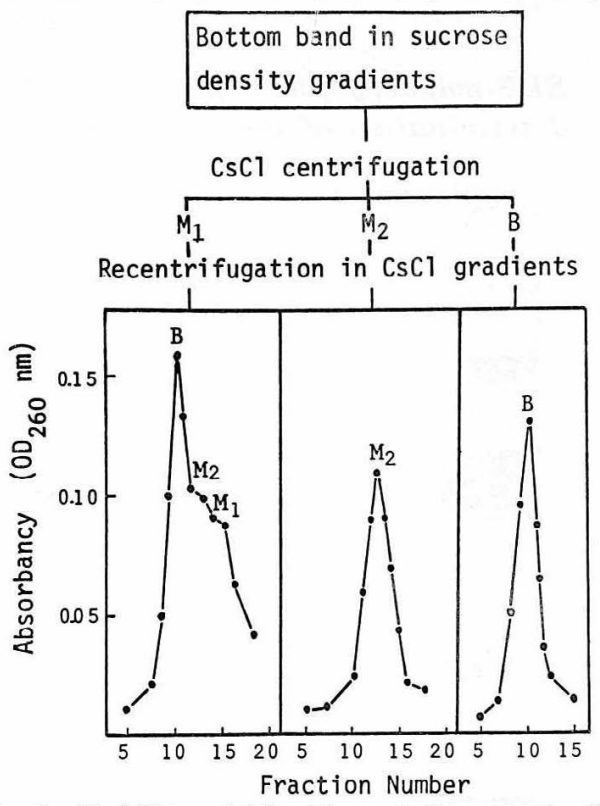

Fig. 5. Stability of $\mathrm{M}_{1}, \mathrm{M}_{2}$ and $\mathrm{B}$ zones in $\mathrm{CsCl}$ density gradients by recentrifugation.

scent. $\mathrm{T}$ was the empty shell (Fig. 4). Buoyant densities of $\mathrm{T}, \mathrm{M}_{1}, \mathrm{M}_{2}$, and $\mathrm{B}$ were $1.26,1.39-1.42,1.43$, and $1.46 \mathrm{~g} / \mathrm{ml}$ respectively. Recentrifugation of these components in $\mathrm{CsCl}$ gradients showed that only $\mathrm{M}_{1}$ yielded $\mathrm{M}_{2}$ and $\mathrm{B}$ (Fig. 5), whereas $\mathrm{M}_{2}$ and $\mathrm{B}$ remaine unaltered, indicating that the latter two are the degradation products of $\mathrm{M}_{1}$ by the shearing effect of $\mathrm{CsCl}$ gradients.

Electron micrographs of these zones revealed that $\mathrm{M}_{1}$ contained intact virions (Fig. 6B) and also degradation intermediates from intact virions toward $\mathrm{M}_{2}, \mathrm{M}_{2}$ 


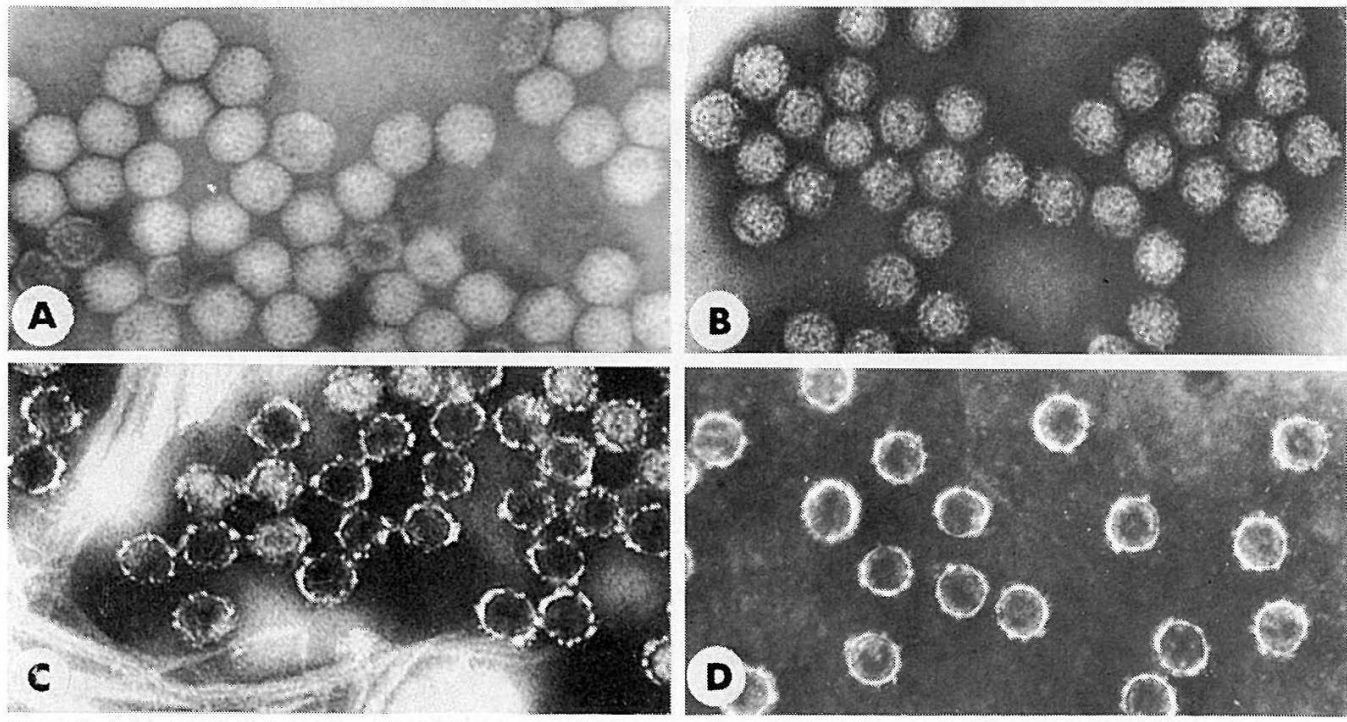

Fig. 6. Electron micrographs of negatively stained: (A) RDV particles prepared from sucrose gradients, (B) $\mathrm{M}_{1}$, (C) $\mathrm{M}_{2}$, (D) $\mathrm{B}$ particles prepared from $\mathrm{CsCl}$ density gradients as shown in Fig. $4 . \times 100,000$.

contained virions on which capsomeres had been loosened (Fig. 6C), and B cores on which a small number of capsomeres still remained attached (Fig. 6D). $\mathrm{M}_{2}$ virions are very unstable in $2 \%$ phosphotungustic acid releasing nucleic acid from virions (Fig. 6C).

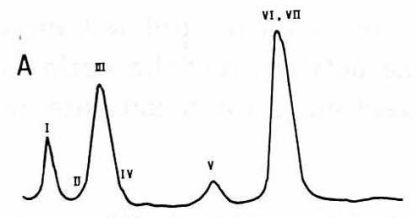

B
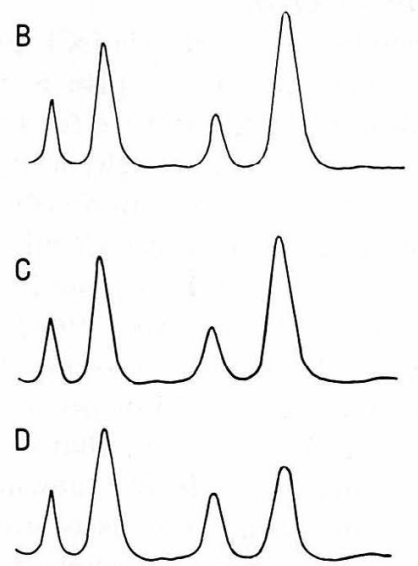

Fig.7. Electrophoresis profiles of $\mathrm{RDV}$ polypeptides of zones in $\mathrm{CsCl}$ density gradients: Top (A) $\mathbf{M}_{\mathbf{1}}$ (B), $\mathrm{M}_{2}$ (C), and B (D).
Electrophoretic separation of polypeptides from each zone obtained by $\mathrm{CsCl}$ density gradient centrifugation

Polypeptide components of the zones, $\mathrm{M}_{1}, \mathrm{M}_{2}$, and $\mathrm{B}$ that were separated by $\mathrm{CsCl}$ density gradient centrifugation were examined by SDS-polyacrylamide gel electrophoresis. No significant difference in the number of polypeptides and their proportions is seen between $M_{1}$ and $M_{2}$ (Fig. $7 B, C$ ), whereas complete loss of II and IV, and marked decrease of VI and VII can be seen in B (Fig. 7D). Results indicate that II, IV, VI, and VII are the components of outer capsid, while I, III, and V are those of core. The decrease of the amounts of VI and VII coincides well with the partial loss of capsomeres as seen in the electronmicrograph of $\mathrm{B}$, indicating that VI and VII compose the capsomeres. II and IV are the minor elements, the amounts of which vary according to the virus samples purified from different materials, indicating that these are unstable in the purification processes, possibly the polypeptides that compose the amorphous protein layer surrounding the capsomeres. 
Table 1. Decrease of RDV-RNA transcriptase activity after $\mathrm{CsCl}$ gradient centrifugation

\begin{tabular}{c|c}
\hline \hline Viral Component & $\begin{array}{c}\text { Transcriptase } \\
\text { Activity (cpm)* }\end{array}$ \\
\hline Intact virion & 31,278 \\
M $_{1}$ & 10,440 \\
$M_{2}$ & 9,680 \\
B & 6,090 \\
\hline
\end{tabular}

* $\mathrm{CsCl}$ was removed by electrophoresis as described in Materials and Methods.

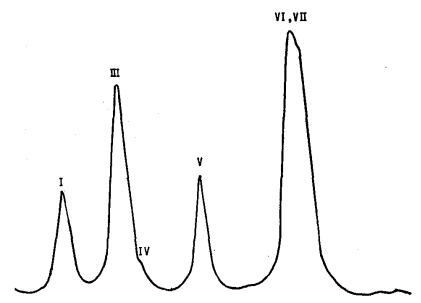

Fig. 8. Electrophoresis profiles of polypeptides of RDV virions after treatment with chymotrypsin.

Table 2. Transcriptase activity of RDV-virions after treatment with chymotrypsin

\begin{tabular}{|c|c|c|c|}
\hline \multicolumn{2}{|c|}{$\begin{array}{c}\text { Incubation* } \\
\text { time } \\
\text { (min.) }\end{array}$} & $\begin{array}{l}\text { Incubation } \\
\text { temperature } \\
\text { (C) }\end{array}$ & $\begin{array}{l}\text { Activity** } \\
\text { (cmp) }\end{array}$ \\
\hline \multirow{5}{*}{ I } & 0 & 25 & 22,415 \\
\hline & 30 & 25 & 21,258 \\
\hline & 60 & 25 & 21,308 \\
\hline & 120 & 25 & 18,196 \\
\hline & 150 & 25 & 21,338 \\
\hline \multirow{5}{*}{ II } & 0 & 35 & 18,688 \\
\hline & 30 & 35 & 18,226 \\
\hline & 60 & 35 & 17,928 \\
\hline & 120 & 35 & 20,731 \\
\hline & 150 & 35 & 19,342 \\
\hline
\end{tabular}

*200 $\mu \mathrm{g}$ of $\mathrm{RDV}$ was incubated in 1 $\mathrm{ml} 1 \times \mathrm{SSC}, \mathrm{pH} 7.4$ containing $200 \mu \mathrm{g}$ chymotripsin.

**Activity was measured as described in Materials and Methods

\section{RNA-transcriptase activities of $M_{1}, M_{2}$ and $B$}

The zones, $\mathrm{M}_{1}, \mathrm{M}_{2}$, and $\mathrm{B}$, separated by $\mathrm{CsCl}$ density gradient centrifugation, were subjected to electropheresis to remove $\mathrm{CsCl}$ and then assayed for their RNA transcriptase activities. Although a great loss of activity occurred in each zone as a result of $\mathrm{CsCl}$ centrifugation, about $1 / 4$ of the original activity was still retained even in $B$, the cores (Table 1). This suggests that I, III, and V, that compose the core, play important roles in the RNA transcription.

\section{Effects of chymotrypsin treatment on $R N A$ transcriptase activity and polypeptide components of virions}

It has been reported by Silverstein et al. ${ }^{9}$ ) and Astell et al. ${ }^{1)}$ that RNA transcriptase activity of reovirus virions is exhibited only when the major outer capsomere protein, $\sigma_{3}$, is removed by chymotrypsin in vitro or by hydrolases contained in the lysosomal compartment in vivo. This is not the case with RDV because the chymotrypsin treatment of RDV virions did not remove any of the polypeptides (Fig. 8) nor enhance RNA transcriptase activity (Table 2). The results are consistent with that of Kodama et al.4) who reported that the presence of chymotrypsin in the reaction mixture did not enhance the RNA transcriptase activity but the optimum $\mathrm{pH}, 8.5$, was the most effective factor to activate the enzyme.

\section{Change of polypeptide components after various treatment of virion}

$\mathrm{RDV}$ virions were incubated (1) in Tris- $\mathrm{HCl}, \mathrm{pH}$ 8.5 , at $35 \mathrm{C}$ for $1 \mathrm{hr}$, (2) in Tris- HCI- $\mathrm{Mg}^{2+}, \mathrm{pH} 8.5$, at $35 \mathrm{C}$ for $1 \mathrm{hr}$, (3) in standard reaction mixture for the assay of RNA transcriptase activity (minus chymotrypsin), at $35 \mathrm{C}$ for $1 \mathrm{hr}$, or (4) suspended in distilled water and treated with 3 repetitions of freeze-thawing. Polypeptide components of the samples were examined by SDS-polyacrylamide gel electrophoresis. Results indicated that VI and VII, that compose capsomeres, are readily removed from virions at a high $\mathrm{pH}, 8.5$, in the absence of $\mathrm{Mg}^{2+}$ (Fig 9, C, D). V, that was thought to compose the core, was easily released from virions by freeze-thawing together with RNA, suggesting that the polypeptide might be intimately associated with RNA in the core. No change in the polypeptide components was found with the

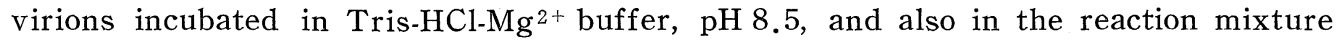
that devoid of chymotrypsin. The results indicate that the presence of $\mathrm{Mg}^{2+}$ in the incubation solution stabilizes attachment of capsomeres to the core surface. 

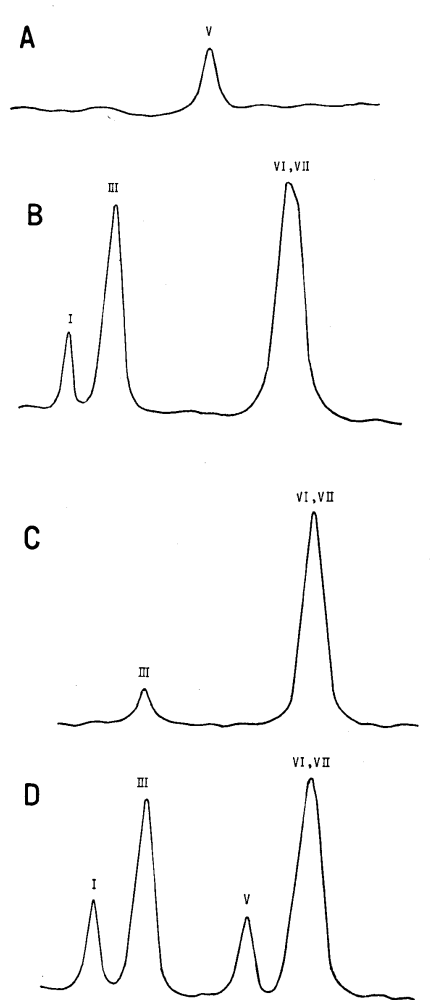

Fig.9. Polyacrylamide gel electrophoresis profiles of polypeptides of RDV virions after treatment with Tris-HCl buffer or freeze-thawing: The sample was treated with freezethawing, then centrifuged at 24,000 rpm for $1 \mathrm{hr}$. supernatant (A) and $\operatorname{pellet}(\mathrm{B})$; The sample was incubated in Tris- $\mathrm{HCl}, \mathrm{pH} 8.5$, for $1 \mathrm{hr}$, then centrifuged at $24,000 \mathrm{rpm} 1 \mathrm{hr}$. Supernatant (C) and pellet (D).

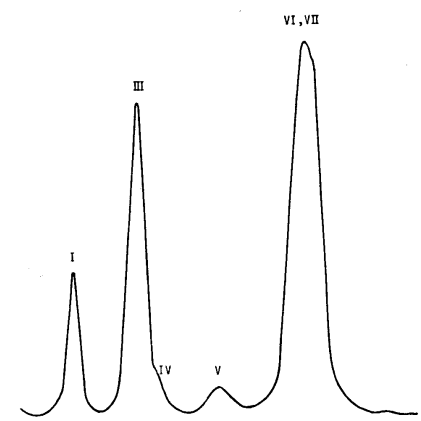

Fig. 10. Polyacrylamide gel electrophoresis profiles of polypeptides of RDV empty shells. in contrast to the yellowish fluorescence of $M_{2}$.
Recentrifugation in $\mathrm{CsCl}$ gradients showed that $\mathrm{M}_{1}$ yielded $\mathrm{M}_{2}$ and $\mathrm{B}$, indicating that the degradation of virions proceeded from $M_{1}$ via $M_{2}$ to $B$. Prolonged centrifugation,

\section{Polypeptide components of empty shells}

Polypeptide components of the empty shells drawn from $\mathrm{CsCl}$ gradients $(1.26 \mathrm{~g} / \mathrm{ml})$ and also from sucrose gradients were examined by SDS-polyacrylamide gel electrophoresis. Results indicate that all the polypeptide components of intact virions are present in empty shells, except that the proportion of $\mathrm{V}$ is much smaller than that in intact virions (Fig. 10).

\section{Discussion}

This study was undertaken to gain some insight into the polypeptide components of RDV virions and their location in the virion structure. Just like reovirus and wound tumor virus, $\mathrm{RDV}$ virions contain seven species of polypeptides. These were tentatively designated I, II, III, IV, V, VI, and VII in the order of molecular weights. Although it was reported by Reddy et $a l .{ }^{7)}$ that the purification procedure of wound tumor virus by using Freon- $\mathrm{CCl}_{4}$ resulted in a loss of some outer shell components, the use of fluorocarbon and $\mathrm{CCl}_{4}$ was necessary for the purification of RDV because RDV virions were otherwise enveloped by a lipid-like material ${ }^{3)}$. The components II and IV were thought to be comparable with 131,000 and 96,000 dalton components of wound tumor virus that surround the capsomeres, because their proportions often varied according to virus samples purified from rice leaves of different ages and those collected in different seasons, possibly due to their susceptibility to fluorocarbon- $\mathrm{CCl}_{4}$ treatment. In this study, the RDV sample purified by fluorocarbon- $\mathrm{CCl}_{4}$ treatment, PEG sedimentation, followed by sucrose density gradient centrifugation were used as the original material for polypeptide analyses.

Unlike reovirus, chymotrypsin could not remove capsomeres of RDV nor enhance RNA transcriptase activity of virions. The only way to remove the outer shell components efficiently was to utilize the shearing effect of $\mathrm{CsCl}$ density gradient centrifugation

In $\mathrm{CsCl}$ gradients, $\mathrm{RDV}$ virions separated into four zones, $T, M_{1}, M_{2}$ and $B$, of which $M_{1}$ was a broad zone almost continuous to $\mathrm{M}_{2}$ but was easily distinguished because of its bluish fluorescence in contrast to the yellowish fluorescence of $M_{2}$. 
e. g., for $12 \mathrm{hr}$, in $\mathrm{CsCl}$ gradients resulted in the increase of $\mathrm{M}_{2}$ and $\mathrm{B}$, and the disappearance of $\mathrm{M}_{1}$ as reported by Reddy et al. ${ }^{7)}$ for wound tumor virus. Centrifugation in $\mathrm{CsCl}$ gradients in Tris-buffer, $\mathrm{pH} 8.5$, showed the same results. Electron micrographs of these zones showed that $\mathrm{T}$ was empty shells, $\mathrm{M}_{1}$ consisted of intact virions and intermediates of various degrees of disruption toward $\mathrm{M}_{2}$, which buoyant densities varying from 1.39 to $1.42, \mathrm{M}_{2}$ the virions on which outer capsomeres were loosened, and B the cores on which capsomeres had been lost not completely but to a great extent.

Since polypeptides II and IV had been completely, and VI and VII partially lost in $B$, these must be the components of the outer shell. II and IV appear to compose the amorphous protein layer that surround the capsomeres because their proportions vary according to the leaf materials of different ages and seasons. VI and VII are the major components that decrease in parallel with the disruption of virions indicating that these are the components of capsomeres. The remaining I, III, and V compose the core, of which V is readily released from virions by freezethawing suggesting that this is the internal protein intimately associated with nucleic acid.

Althrough $\mathrm{CsCl}$ density gradient centrifugation greatly reduced RNA transcriptase activity of virions, $M_{1}, M_{2}$ still retained about $1 / 3$, and $B$ about $1 / 4$ that of the original intact virions, indicating that the components of core, i. e., I, III, and V must play important roles in the enzyme action.

Incubation of virions in Tris- $\mathrm{HCl}, \mathrm{pH} 8.5$, for $1 \mathrm{hr}$ at $35 \mathrm{C}$ caused loss of $\mathrm{VI}$ and VII, whereas incubation in Tris- $\mathrm{HCl}-\mathrm{Mg}^{2+}, \mathrm{pH} 8.5$, caused no change of polypeptide components. This was also the case with the incubation of virions in the reaction mixture in which $8 \mathrm{mM}$ of $\mathrm{Mg}^{2+}$ was present and essential for the enzyme reaction. These results indicate that capsomeres remain attached on the virions that are producing RNA in the reaction mixture where $\mathrm{Mg}^{2+}$ is present. This is a striking contrast to reovirus, in which RNA transcriptase is activated only when virions are

Table 3. Correspondence of genome segment size of RDV to the size of virus-polypeptide

\begin{tabular}{|c|c|c|c|c|c|}
\hline \multirow{3}{*}{$\begin{array}{l}\text { RDV } \\
\text { No. }\end{array}$} & \multirow{3}{*}{$\begin{array}{l}\text { genome segment } \\
\text { M. W. }\left(\times 10^{6}\right)^{*}\end{array}$} & \multicolumn{4}{|c|}{ RDV polypeptide species } \\
\hline & & \multicolumn{2}{|c|}{ Moleculur weight } & \multirow{2}{*}{ No. } & \multirow{2}{*}{ Location } \\
\hline & & Calculated** & Obserbed & & \\
\hline 1. & 3.10 & 194,000 & 193,000 & I & core \\
\hline 2. & 2.50 & 156,000 & 152,000 & II & outer protein layer \\
\hline 3. & 2.20 & 137,500 & 131,000 & III & core \\
\hline 4. & 1.80 & 112,500 & & & \\
\hline 5. & 1.76 & 110,000 & 110,000 & IV & outer protein layer \\
\hline 6. & 1.05 & 65,600 & & & \\
\hline 7. & 1.02 & 63,700 & 62,000 & $\mathrm{~V}$ & core \\
\hline 8. & 0.78 & 48,800 & 46,000 & VI & underlying capsomere \\
\hline 9 & 0.70 & 43,000 & 45,000 & VII & underlying capsomere \\
\hline 10. & 0.67 & 41,900 & & & \\
\hline 11. & 0.48 & 30,000 & & & \\
\hline 12. & 0.48 & 30,000 & & & \\
\hline
\end{tabular}

* Moleculure weights were taken from Reddy et al. (1974).

** Mol. W. of poly peptide $=$ Mol. W of RDV genome segment $\times$ Mol. W. of amino acid (120) Mol. W. of RDV base pair $(640) \times 3$ 
converted into subviral pariticles in vivo or into cores by the action of chymotrypsin in vitro.

RDV-genome has been reported to consist of 12 dsRNA segments of known molecular weights ${ }^{2,6)}$. If we assume that the mRNA that is transcribed from each of the dsRNA segment is monocystronic, the molecular weight of polypeptide translated from each mRNA can be calculated from molecular weight the respective dsRNA segment. The relationship between molecular weights of genome segments and those of virion-polypeptides are shown in Table 3 . The table also indicates the location of each polypeptide in the structure of virion.

\section{Literature cited}

1) Astell. G., Silverstein, S. C., Levin, D. H. and Acs, G. (1972). Virology 48: 648-654.

2) Fujii-Kawata, I. and Miura, K. (1970). J. Mol. Biol. 51: 247-253.

3) Fukushi, T., Shikata, E. and Kimura, I. (1962). Virology 18: 192-205.

4) Kodama, T. and Suzuki, N. (1973). Ann. Phytopath. Soc. Japan 39: 251-258.

5) Nakata, M. and Suzuki, N. (1975). ibid 41: 345-355.

6) Reddy, D. V. R., Kimura, I. and Black, L. M. (1974). Virology 60: 293-296.

7) Reddy, D. V. R. and Macleod, K. (1976). ibid 70: 274-282.

8) Shapiro, A. L., Vinuela, E. and Maizel, J. V. (1967). Biochem. Biophys. Res. Commur. 28: 815-820.

9) Silverstein, S. C., Astell, C., Levin, H., Schonberg, M. and Acs, G. (1972). Virology 47, 797-806.

10) Smith, R. E., Zweerink, H. J. and Joklik, W. K. (1969). Virology 39: 791-810.

11) Suzuki, N., Kimura, I. and Kodama, T. (1973). Ann. Phytopath. Soc. Japan 39: 1-6.

12) Yanagi, N., Nakata, M. and Suzuki, N (1975). J. Pesticide Sci. 1: 107-114.

和 文 摘 要

イネ萎縮病ウイルス粒子の構成ポリペプチド

中田 昌伸・福永 憲三・鈴木 直治

イネ萎䋗病ウイルス感染葉から分離したウイルス標品はSDS-ポリアクリルアミドゲル電気泳動によって 7 種のポリペプチドに分離された。泳動距離の短かい方から順に I 〜VII とした。それぞれの分子量は193,000 ; 152,$000 ; 110,000 ; 62,000 ; 46,000 ; 45,000$ ダルトンであった。 キモトリプシン処理によって外殼ポリペ プチドは除かれなかった。 $\mathrm{CsCl}$ 濃度勾配平衡遠心によって $\mathrm{M}_{1}, \mathrm{M}_{2}, \mathrm{~B}$ の三成分に分かれ，それぞれの浮 遊密度は1.39 1.42, $1.43,1.46 \mathrm{~g} / \mathrm{ml}$ であり， $\mathrm{CsCl}$ 内での遠心による shearing force を受けて粒子は $\mathrm{M}_{1} \rightarrow \mathrm{M}_{2} \rightarrow \mathrm{B}$ 々変化したものと考えられる。電子顕微鏡観察之電気泳動から B は II と IV が完全に, VI VII が一部除かれたものであり，II と IV は最外殼を形成する不定形のポリペプチド，VI と VII はカプソ メアを形成するポリペプチドと考えられる。I，III，Vはココを形成するポリペプチドと推測され，Vは凍 結融解によって核酸と共に粒子から漏出するととから核内のポリペプチドと考えられる。 